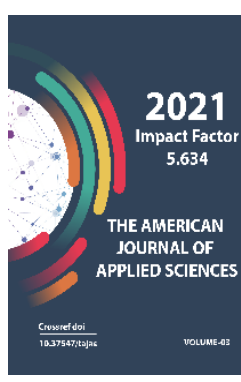

Journal Website: http://usajournalshub.c om/index,php/tajas

Copyright: Original content from this work may be used under the terms of the creative commons attributes 4.0 licence.

\section{Competitive Environment, Quality And Its Management In The Digital Economy}

Olim Sabirovich Kazakov

Candidate Of Economic Sciences, Professor, Department Of Management, Namangan Engineering-Technological Institute, Uzbekistan

\section{Shaxboz Valijonov}

Master Of Specialization Of Management, Namangan Engineering-Technological Institute, Uzbekistan

\title{
ABSTRACT
}

In the context of globalization and digitalization of the economy, the competitiveness of products is important. Improving product quality is required to ensure competitiveness. The article discusses the issues of production of quality products and issues of ensuring competitiveness. The main directions of ensuring the competitiveness of products have been identified and ways to improve product quality management have been proposed.

\section{KEYWORDS}

Digital economy, competitiveness, quality, quality management, information technology, export, planning.

\section{INTRODUCTION}

Thanks to the large-scale reforms carried out under the leadership of President Shavkat Mirziyoyev to raise the development of Uzbekistan to a new level in the recent stages of economic development, radical changes are taking place in the life of our people. In these processes, new values and traditions are being formed in our society. The development of 
industrial enterprises operating in the country, the formation of a competitive environment among them will further increase the aspirations of enterprises to produce quality products. At the same time, it is necessary to take responsibility for the production of industrial products directly at the enterprise in accordance with the requirements of international quality standards. Improving the mechanism of improving product quality in accordance with the requirements of international quality standards and studying the factors influencing it and the causes of this situation.

One of the important tasks in today's modern enterprises is to study the problems that arise in the production of quality products, taking into account the requirements of the digital economy, and to analyze this situation and improve the management of these processes.

The modern market economy places strict demands on the quality of the products produced. Because the survival of any firm today, its strong position in the market of goods and services is determined by the level of competitiveness. Competitiveness is related to two indicators - price and the level of product quality.

\section{THE MAIN PART}

In the current transition to a digital economy, diversification of production is underway. Under such conditions, the competition intensifies. During this period, the second factor, namely the quality of products and services, is gaining priority. Because quality is an important basis for the reputation and further development of the enterprise. Therefore, quality management needs to be improved and adapted to the conditions in this context. Quality management is the beginning and end of the work for all employees, from the manager to the specific executor. Due to this, the issue of quality plays an important role in the economic, including industrial policy of the state. Improving the quality of a product is, as a result, a matter of saving its quantity and resources used, fully satisfying social and personal needs. That is, any product must meet the highest technical, economic and aesthetic requirements, as well as a number of other requirements, be able to compete in the world market. If the problem of quality is not solved, social production and the needs of the population in goods cannot be met.

Product (work, service) quality is a set of characteristics that determine whether a particular product is perfect for use in all aspects.

The quality of industrial products is one of the main indicators used in planning and determining the activities of the industry, enterprise (firm). It describes the organization of labor, its level of equipment, the qualifications of specialists, the state of production management.

Product quality is economically expressed in the form of a measure of consumption value and the degree of use. Product quality is an economic category that reflects the relationship between producers and consumers, the relationship of the enterprise with the state in the production of quality products, the implementation of planned tasks and product pricing. In addition, product quality represents the relationship between enterprises for material incentives for quality 
products and for material liability for the production of substandard products.

When a consumer buys a product in the market as a buyer, he always compares the price of the item to know that it covers the set of properties he has. Economically optimal quality means the ratio of quality and cost or the price per unit of quality, and it is calculated by the following formula:

Copt $=\mathrm{Bs} / \mathrm{Xe}$

Here: Copt - economically optimal quality;

Bs - product quality;

Xe - cost of purchase and operation of the item, UZS.5

Determining the denominator of a formula is not complicated because it includes the selling price of the item, the cost of operation, repair, and disposal. Determining the speed of the formula, on the other hand, is more difficult because the quality of the product is so many and varied. A separate science "Qualimetry" deals with this. He developed a sufficiently satisfactory method of estimating quality in terms of quantity, that is, the growth of a unit of product quality at a cost of one soum.

So, in modern production conditions, product quality is an important component of the efficiency and profitability of the enterprise (firm). Therefore, it is necessary to pay constant attention to it. Quality should be dealt with by everyone from the CEO to the specific executor. All processes of quality assurance, design, maintenance are integrated into the quality management system.

\section{RESULTS AND DISCUSSION}

Improving quality and ensuring competitiveness in the activities of enterprises and organizations are important tasks. All enterprises and organizations in Namangan region are improving their activities in this area.

Through the following analyzes, it is possible to think about the level of quality and competitiveness.

Table 1

Industrial products in Namangan region in 2017-2020 production, billion soums

\begin{tabular}{|c|c|c|c|c|c|c|}
\hline № & Кўрсаткичлар номи & 2017 Year & 2018 Year & 2019 Year & $\begin{array}{c}2020 \\
\text { Year }\end{array}$ & Total share,\% \\
\hline 1 & By region & 4614,5 & 6586,5 & 8873,5 & 10950,8 & 100,0 \\
\hline & $\begin{array}{c}\text { Growth rate compared } \\
\text { to } 2017\end{array}$ & 1 & 1,42 & 1,92 & 2,37 & \\
\hline 2 & Manufacturing products & 4354,8 & 6204,3 & 8052,2 & 9189,3 & 83,9 \\
\hline 3 & Food production & 1162,4 & 1272,1 & 1776,6 & 2227,9 & 20,3 \\
\hline
\end{tabular}


The American Journal of Applied sciences

(ISSN - 2689-0992)

Published: April 29, 2021 | Pages: 119-125

\begin{tabular}{|c|c|c|c|c|c|c|}
\hline 4 & $\begin{array}{c}\text { Production of } \\
\text { beverages, juices }\end{array}$ & 198,3 & 239,7 & 371,6 & 417,4 & 3,8 \\
\hline 5 & $\begin{array}{c}\text { Manufacture of textile } \\
\text { products }\end{array}$ & 1775,8 & 2132,0 & 2465,4 & 2448,6 & 22,4 \\
\hline 6 & Manufacture of clothing & 788,3 & 821,8 & 1173,4 & 1439,3 & 13,1 \\
\hline 7 & $\begin{array}{c}\text { Manufacture of leather } \\
\text { and related products }\end{array}$ & 122,3 & 169,6 & 199,9 & 191,3 & 1,7 \\
\hline
\end{tabular}

Table 1 analyzes the indicators of industrial production in the region in 2017-2020. It can be seen that the volume of industrial production has been growing over the years. Its growth rate was $237 \%$ in 2020 compared to 2017.

Table 2 below analyzes the implementation of export operations in the region in 2019-2020. From it it can be seen that in 2020 the export operations in the region were performed by $6.2 \%$ more than in 2019. In 2020, the volume of industrial production increased by $23.0 \%$ compared to 2019, and the volume of exports increased by only $6.2 \%$. This means that a number of measures are needed to ensure competitiveness in the region by improving quality.

Table 2

Analysis of the implementation of export operations in Namangan region in 2019-2020

\begin{tabular}{|c|c|c|c|c|}
\hline № & Cities and districts & 2019 Year & 2020 Year & $\begin{array}{c}\text { Growth rate in } \\
\text { 2020 compared to } \\
2019\end{array}$ \\
\hline 1 & Namangan City & 113265,4 & 102048,7 & 90,1 \\
\hline 2 & Mingbulak & 7374,7 & 20641,8 & 279,9 \\
\hline 3 & Kasansay & 33221,3 & 19675,3 & 59,2 \\
\hline 4 & Namangan & 19845,9 & 21959,8 & 110,7 \\
\hline 5 & Norin & 14445,2 & 24012,6 & 166,2 \\
\hline 6 & Pop & 13656,0 & 12918,4 & 94,6 \\
\hline 7 & Turakurgan & 52818,8 & 62589,3 & 118,5 \\
\hline 8 & Uychi & 28854,6 & 23763,3 & 82,4 \\
\hline 9 & Uchkurgan & 16914,8 & 20645,0 & 122,1 \\
\hline 10 & Charrtak & 6530,7 & 17546,8 & 268,7 \\
\hline 11 & Chust & 20346,6 & 16907,3 & 83,1 \\
\hline
\end{tabular}


The American Journal of Applied sciences

(ISSN - 2689-0992)

Published: April 29, 2021 | Pages: 119-125

\begin{tabular}{|c|c|c|c|c|}
\hline 12 & Yangikurgan & 26028,5 & 32030,8 & 123,1 \\
\hline 13 & Individuals & 2743,7 & 3277,0 & 119,4 \\
\hline & By region & 356046,5 & 378016,2 & 106,2 \\
\hline
\end{tabular}

Enterprises and organizations should prioritize competitiveness in their activities. If this were done, the increase in the region's export activities could reach $20.0 \%$ and higher in 2020 . This means that a number of measures are needed to improve quality and ensure competitiveness, develop an action plan and implement them. The most important of these activities is quality management, which includes:

1. Quality planning to increase competitiveness.

2. Organization of work on quality and its assurance.

3. Establish quality control in the enterprise.

4. Analysis of product quality measures and product quality.

5. Encourage quality improvement.

To improve product quality management, the following issues need to be addressed:

1. Product quality control.

2. Product quality assessment.

3. Implement product quality management and a systematic approach to it.

4. To study the relationship of product quality management with the factors affecting it.

The most important management function in improving the quality of products is the organization of quality control. The essence of quality control is to obtain information about the object to be inspected and compare it with the requirements, standards and requirements of the concluded contracts.

To improve product quality management, the following issues need to be addressed:

1. Product quality control.

2. Product quality assessment.
3. Implement product quality management and a systematic approach to it.

4. To study the relationship of product quality management with the factors affecting it.

\section{CONCLUSIONS AND SUGGESTIONS}

1. In the context of digitization and modernization of the economy, the quality factor is becoming more important. Because quality is the reputation and further prosperity of the enterprise, and the work on quality management is the most responsible activity for all employees, from the manager to the specific executor. Due to this, the issue of quality plays an important role in the economic, including industrial policy of the state. Improving the quality of the product - this ultimately leads to an increase in its quantity, saving resources, more complete satisfaction of social and personal needs. That is, any product must meet the highest technical economic and aesthetic requirements, as well as a number of other requirements, be able to compete in the world market. If the problem of quality is not solved, the needs of social production and the population in goods cannot be met.

2. It is advisable that the product quality management process consists of the following operations:

- Determining the level of product quality;

- Collection and study of information on the product and the process of its production, which affects the quality of the product;

- Decision-making on product quality management and preparation for exposure to the object;

- Issue management orders; 
- Collection and analysis of information on changes in product quality as a result of management.

3. The following tasks are performed in product quality management:

- Long-term assessment of the technical level and quality of the product;

- Planning and forecasting of product quality improvement;

- Product quality certification;

- Design and implementation of product design;

- Logistical support of product quality;

- Technological preparation of production;

- Organization of product quality measurement;

- Selection, placement, training and education of specialists;

- Uniform level of production of quality products;

- Organization of maintenance, repair of means of production;

- Encouragement to improve product quality;

- Product quality control;

- Compliance with standards, measuring instruments and specifications;

- Ensuring the right to manage product quality.

4. Certain costs are incurred by manufacturing enterprises to improve the quality of products. These costs are called quality path costs. As costs increase, so do the prices of products. This is an additional cost for buyers. Therefore, an increase in the price of a product or service requires an increase in the efficiency of that product for the consumer. As the consumer value of products increases, buyers can spend more money on these products. Otherwise, consumers will not spend extra money on these products. As a result, the products produced by the enterprise remain unsold.

5. If a manufacturing enterprise strives to make more profit for the products it produces, it must also take into account the interests of consumers, i.e., reduce consumer prices. In this case, the products and services created by the manufacturer can be sold quickly in the market. In this case, both producers and consumers can benefit greatly. Producers can use the profits in the development of science and technology in production, as well as in the expansion of production.

\section{REFERENCES}

1. Decree of the President of the Republic of Uzbekistan dated November 3, 2017 No PP-3351 "On measures to further liberalize foreign trade and support businesses."

2. Resolution of the President of the Republic of Uzbekistan dated August 23, 2017 No PP-3238 "On measures for further introduction of modern energy efficient and energy saving technologies."

3. Decree of the President of the Republic of Uzbekistan "On the Strategy of actions for further development of the Republic of Uzbekistan" Tashkent, February 7, 2017 "Namangan Haqiqati" newspaper, February 11, 2017 № 12

4. BogatinYu.V.

Ekonomicheskayaotsenkakachestvaieffek tivnostrabotpredpriyatiy. Moscow, Economics, 1992

5. OlimSabirovichKazakov, \&llhomMahamadjanovichKamoliddinov. (2021). SOME QUESTIONS OF INCREASE OF EFFICIENCY IN ACTIVITY ENTERPRISE SUBJECTS. Journal of Central Asian Social Studies, 2 (01), 160-169. https://doi.org/10.37547/jcass/volume02iss ue01-a24

6. KazakovO. (2020). WAYS TO DEVELOP MANUFACTURING ACTIVITIES IN A SMALL BUSINESS. Archive of scientific research, 1 (2) .vote from https://tsue.scienceweb.uz/index.php/arc hive/article/view/3729

7. International standards ISO series 90002000: Methodical recommendations for 
application. / E.S. Balandin, V.G. Yudaeva.Ulyanovsk: UIGTU, 2003. - 90 p.

8. Kazakov, O. S., \&Ahmedkhodjaev, X. T. (2017). Fundamentals of management. Tashkent, Ilm-Ziyo.

9. Kazakov O. (2020). IMPROVING THE MANAGEMENT ACTIVITY OF THE FRUIT AND VEGETABLE INDUSTRY ENTERPRISES. Archive nauchnyxissledovaniy, 1 (2). taken from https://tsue.scienceweb.uz/index.php/arc hive/article/view/3731

10. Qozoqov, O. docent and Qozoqov, S. (2020) "WAYS TO INCREASE THE EFFICIENCY OF USING EQUIPMENT AND TECHNOLOGY IN THE CONDITIONS OF DIGITAL ECONOMY," International Finance and Accounting: Vol. 2020: Iss. 5, Article 30.

Available at: https://uzjournals.edu.uz/interfinance/vol 2020/iss5/30

11. Scientist SabirovichKazakov, \&llhomMahamadjanovichKamoliddinov. (2021). SOME QUESTIONS OF INCREASE OF EFFICIENCY IN ACTIVITY ENTERPRISE SUBJECTS. Journal of Central Asian Social Studies, 2 (01), 160-169. https://doi.org/10.37547/jcass/volume02iss ue01-a24

12. LutfullaKhabibullayevichUbaydullayev, \& Bakhtiyor NabijanovichDedajanov. (2021). THE DIGITAL ECONOMY: ADVANTAGES AND RISKS. Journal of Central Asian Social Studies, 2 (01), 153-159. https://doi.org/10.37547/jcass/volume02iss ue01-a23

13. Nabijanovich, D. B. (2019). Issues of support and stimulation of exporting enterprises and ways of their elimination. American Journal of Economics and Business Management, 2 (3), 44-56. 